\title{
Unfinished Nation-Building in Belarus and the 2006 Presidential Election
}

\author{
Grigory Ioffe ${ }^{1}$
}

\begin{abstract}
A U.S.-based geographer interprets the results of the March 19, 2006 presidential elections in Belarus as a contest among three emergent strands of Belarusian nationalism. The study is based on national surveys conducted by an independent research/polling organization, analysis of websites of Radio Liberty's Belarusian Service and opposition-minded and official media outlets, as well as field observations and selected interviews. The author begins by examining polling results believed to reflect mass attitudes of rank-and-file Belarusians; the three strands of nationalism (personified by the three major presidential candidates) are then described in detail. He argues that lack of national consolidation presents a far greater problem for Belarus than the much-reviled Lukashenka regime, particularly in the context of recent disputes with Russia over oil and gas transit and pricing. Journal of Economic Literature, Classification Numbers: O18, P20, Z00. 5 tables, 70 references. Key words: Belarus, Lukashenka, national identity, independent media, Creole nationalism, Russia, Poland, national projects.
\end{abstract}

66 hat is more important to you, economic improvement or national independence?" read one question in the November 2003 national survey conducted by the Independent Institute for Socio-Economic and Political Studies (IISEPS). ${ }^{2}$ The result was a 62 vs. 25 percent response in favor of economic improvement. Even among self-proclaimed "supporters of the opposition," the ratio was 51.4 vs. 35.9 percent (IISEPS, 2003). Perhaps even more startling than the result was the fact that the question was asked in the first place. Such a question would have been extremely unlikely for any public survey in Russia, Poland, Latvia, or Lithuania because in those countries statehood is conceived to be of existential importance and not subject to tradeoff for a higher standard of living. ${ }^{3}$

Just a week following the March 2006 presidential election in Belarus, much criticized in the Western media, the IISEPS conducted yet another national survey. One question in it read: "Do you consider yourself a European or a Soviet man/woman?" Fifty-two percent

\footnotetext{
${ }^{1}$ Professor, Department of Geography, Radford University, Radford, VA 24142 (gioffe@radford.edu). The author gratefully acknowledges Yury Drakakhrust's helpful advice and consultation.

${ }^{2}$ IISEPS is an opposition-minded Minsk-based think tank and polling firm headed by the sociologist Dr. Oleg Manayev, which was subjected to harassment by the Belarusian KGB in December 2004. On December 27, 2004, the U.S. Ambassador to Belarus visited IISEPS as a sign of support for beleaguered Belarusian NGOs. On April 15, 2005, the Supreme Court of Belarus ruled in favor of closing the institute; it has since continued operations as a nonprofit organization registered in neighboring Lithuania. Manayev has been repeatedly warned by the General Prosecutor's Office that polling operations in Belarus by an institution not registered within the country is a criminal offense, although Manayev has maintained that the polling is being conducted by a group of private citizens.

${ }^{3}$ In Ukraine, another Belarus neighbor, the responses to this question likely also would be different, except perhaps for some regions in the east and south.
} 
identified with Soviet and 36 percent with European. Another question in the survey was: "If you were to choose between the unification with Russia and joining the European Union, which would you choose?" Here, 51.6 percent opted for unification with Russia, whereas 24.8 favored joining the EU (52\% Belorusov, 2006). While the applicability of these and other surveys is discussed below, the above-cited responses provide a useful context for framing statistics pertaining to Belarusian elections.

\section{THE 2004 REFERENDUM AND THE PRESIDENTIAL RACE}

In May 2004, the date of a constitutional referendum was set for October 17, 2004, on the same day as parliamentary elections. The referendum queried Belarusians about whether they would allow the incumbent President Alyaksandr Lukashenka to participate in the upcoming presidential race and accept a new version of article 81 of the Belarus constitution that would dispose of the presidential maximum of two consecutive five-year terms. More than 50 percent of the vote was required to adopt the constitutional amendment. In any event, official statistics indicated that 79.4 percent of registered voters approved the measure, as opposed to the 48.4 percent approval rating indicated by exit polls administered by the Lithuanian arm of the Gallup Institution (Bolonskaya, 2004).

Contrary to rumors and expectations that the congress of the united opposition would have to be held outside Belarus because no premises spacious enough to host 800 people would be provided by Belarusian authorities, the meeting actually took place in Minsk in the Palace of Culture of the Tractor Factory. On October 2, 2005, Alyaksandr Milinkevich ${ }^{4}$ was elected the united opposition candidate. The congress was attended by members of five parties, including the Belarusian Popular Front, United Civic Party, and a splinter Communist Party.

The date of the presidential elections was determined in early December 2005 following a parliamentary vote held on a short notice. The date (March 19, 2006) took the Belarusian opposition by surprise, as it was set almost six months prior to the expiration of Lukashenka's second term in office. This provided limited time for the opposition to campaign on behalf of its candidate. Nonetheless, Milinkevich traveled to all oblast capitals and many larger rayon centers of Belarus, so that by mid- to late December 2005 his name recognition had increased significantly. ${ }^{5}$ By all accounts, however, Milinkevich was more successful in his PR campaign outside Belarus, undertaken to enlist support and demonstrate the acceptance of the Belarusian opposition in Western capitals relative to Lukashenka and members of his team (who are persona non grata in the EU and United States). ${ }^{6}$

${ }^{4}$ Milinkevich, who has a doctorate in physics, served as vice-mayor of Grodno responsible for culture and education from 1990 to 1996. During his tenure many Belarusian-language schools were opened in the city. In 2001, Milinkevich headed the staff of Siamion Domash, the only opposition-minded presidential hopeful (out of five) who spoke fluent Belarusian.

${ }^{5}$ According to a December 2005 poll by IISEPS (2005), given a choice between Lukashenka and Milinkevich, 55 percent would have voted for Lukashenka and 18 percent for Milinkevich. According to the Baltic arm of the Gallup Institute, the ratio of 53 vs. 21 percent was the highest rating Milinkevich obtained in any poll.

${ }^{6} \mathrm{~A}$ long list of European dignitaries met with Milinkevich before the elections, including the Chairman of the European Commission, President of the European Parliament, Secretary-General of the Council of the EU, the Chancellor of Germany, and the presidents of Poland and Lithuania. Milinkevich spoke at a meeting of the Parliamentary Assembly of Europe and in the Polish Seim (Parliament). However, attempts to organize a high-level reception of the united opposition candidate in Moscow failed, despite the fact that Milinkevich repeatedly claimed that in Belarus an anti-Russian politician has no chance to be elected, which is why he is not such a politician. 
Cerebral, soft-spoken, and versed in Belarusian, Russian, Polish, French, and English, Milinkevich was a sharp contrast to Lukashenka, a firebrand with a peasant background and folksy demeanor. By his own admission, Milinkevich "is a Belarusian whereas Lukashenka is a Soviet man" (Boichenya, 2006). Indeed, whereas Lukashenka speaks trasianka, a dialect that is lexically Russian and phonetically Belarusian, Milinkevich speaks good Russian and Belarusian, and does not mix them. Addressing the question of why Milinkevich speaks in Russian on television, his press secretary Pavel Mazheika, noted: "A multitude of our supporters from the regions begged us tearfully that the major part of the speech be in Russian. This was to prevent the state propaganda from affixing the tag of fascist and nationalist [read "xenophobe"-G. I.] on Milinkevich" (Chamu, 2006). Intriguing in this remark is both the assertion that state propaganda would label someone in this way, as well as the wellgrounded suspicion that doing so would strike a chord with many Belarusians.

Although Milinkevich was not a member of any party, the official media and Lukashenka personally portrayed him as a beneefovets - a member of the Belarusian Popular Front, to which so many Belarusians are allergic. The country's leading official daily, Belarus Segodnya, which along with its current title bears the logo of Sovetskaya Belorussiya (as a clear mark of succession), did not, to the author's knowledge, publish overtly negative or libelous materials demeaning Milinkevich. The tone set in a few articles, wherein Milinkevich was mentioned at all, was rather condescending. ${ }^{7}$ Perhaps the most intriguing streak in preelection portrayals of Milinkevich was that he is a Catholic and has overly close relations to the Poles. ${ }^{8}$ The issue of putative belonging to a neighboring ethnicity is a delicate one. "The only thing that worries me," said Svetlana Alexievich,9 "and I trust that this would worry a significant part of our society, is that Milinkevich is of a Polish type, and with this some historic injustices and complexities are associated that stand between us and the Polish society and Catholicism. I am afraid that this will harm [Milinkevich] to some extent ..." (Tsi z'yavilas, 2006).

Readers with limited background in Belarus's history and human geography may wonder why on earth the issue of Milinkevich's putative Polishness matters. It appears that in Belarus, whose major historical predicament has been its "lasting existence in the shadow of Russian and Polish cultures" (Meckovskaya, 2003, p. 61), allusions of belonging to one or the other of those magnets strikes a sensitive chord. One should also keep in mind the somewhat asymmetric relationships with Russians and Poles etched in the historical memory of many Belarusians. Whereas people with Polish identity attempted to "civilize" the Orthodox peasantry living in the Wschodnie Kresy Polskie (Poland's Eastern Periphery), ${ }^{10}$ the message sent by Russians to Belarusian peasantry was "you are us."

\footnotetext{
7"Milinkevich is an ordinary middle-aged man, probably a decent family man and nice to talk to. What I cannot fathom, though, is what nudges those pleasant people to take part in a presidential election. After all, presidency in Belarus is not a safe heaven like a department at the University of Grodno ... One has to know at the least what the difference is between a tractor and a silage cutter and have a clear understanding that potato pancakes do not grow on trees" (Yakubovich, 2006).

${ }^{8}$ This ran contrary to Milinkevich's own assertions that he is from an Orthodox family, and some of his ancestors fought for the Belarusian national cause.

${ }^{9} \mathrm{~A}$ Belarusian author with the highest name recognition outside Belarus, due to her book Voices from Chernobyl: Chronicle of the Future (Alexievich, 1999), later reprinted in the United States under a title Voices from Chernobyl: the Oral History of a Nuclear Disaster (Alexievich, 2005). In 2006, Alexievich received a National Book Critics Circle Award for that book.

${ }^{10} \mathrm{An}$ excellent treatment of this issue can be found in Rykiel (2006, pp. 135-142).
} 
Table 1. Responses to the Question, "If Presidential Elections Were Tomorrow, Who Would You Vote For?" (in percent of all responses)

\begin{tabular}{lrrrrrrrrrrrr}
\hline \hline \multicolumn{1}{c}{ Month.year: } & 10.01 & 04.02 & 09.02 & 12.02 & 03.03 & 09.03 & 06.04 & 11.04 & 03.05 & 05.05 & 09.05 \\
\hline Lukashenka & 46.0 & 30.9 & 27.0 & 30.5 & 26.2 & 31.7 & 34.2 & 47.7 & 46.4 & 41.7 & 47.3 \\
Other candidate $^{\mathrm{a}}$ & 11.8 & 8.3 & 6.5 & 5.0 & 2.6 & 4.0 & 3.0 & 1.5 & 1.4 & 2.0 & 3.5 \\
Stumped for an answer & 24.1 & 15.7 & 25.5 & 18.7 & 31.9 & 25.0 & 23.1 & 16.5 & 17.6 & 22.3 & 18.1 \\
No response & 11.7 & 16.8 & 16.2 & 17.0 & 14.0 & 11.2 & 16.5 & 18.5 & 15.0 & 12.2 & 10.5 \\
\hline
\end{tabular}

${ }^{a}$ Refers to the alternative candidate with the highest rating among the candidates named by the respondents.

Sources: Bykovskiy, 2006; national surveys of the IISEPS. $N=$ nearly 1500 randomly sampled respondents; sample error is within the range of 3 percent.

During the run-up to the elections, Lukashenka opined that because the opposition is bedeviled by a perennial fight for outside money (Western grants), as many as 10 "single" candidates might eventually emerge. Although that prediction proved wrong, one person did in fact break the united opposition front to register as a candidate-Alyaksandr Kazulin, former rector of Belarusian State University and former Minister of Education. ${ }^{11}$ Announcing his candidacy, Kazulin claimed that whereas Milinkevich was a pro-American and proWestern candidate, he (Kazulin) would stand for a balanced foreign policy maintaining good relations with both Russia and the West. ${ }^{12}$ While no reliable pre-election forecast predicted a decent showing, much less a victory for either of the opposition candidates, the fact that Milinkevich and Kazulin effectively split the protest vote made Lukashenka's victory all the more inevitable.

\section{POPULARITY OF PRESIDENTIAL CANDIDATES}

Regular national surveys by the IISEPS enable one to track changes in Lukashenka's popularity rating over time (Table 1). Peaks are evident in 2001 (the year of the second presidential election) and in 2005 (on the eve of the third election). A comparison of the above ratings with the annual dynamics of salaries and pensions reveals that the steepest increases coincided with presidential elections. ${ }^{13}$ Indeed, most Belarusians assert that their quality of life is improving. Comparison of June 2004 and June 2006 responses to the question, "What are the most acute problems that the country and its citizens face?" (Table 2) is especially revealing. Of particular importance is the steep reduction (from 58 to 19.5 percent) in the share of those naming pauperization as the most acute problem and the steadily low percentages of respondents concerned about international isolation and the decline in national culture.

\footnotetext{
${ }^{11}$ Kazulin had been fired as rector amidst accusations of corruption which, however, were not upheld in court.

${ }^{12}$ Kazulin apparently assumed that Milinkevich's base of support in Russia was slim, and that the Russian political elite, wary of Lukashenka's brinkmanship, might decide to focus their support on someone who would maintain ties with Russia but prove a more reliable and predictable partner. Further, it was clear to Kazulin that while many Belarusians disapproved of Lukashenka's policies, very few supported the pet ideas of the Belarusian Popular Front (such as eliminating Russian as an official language of Belarus), with which Milinkevich was associated.

${ }^{13}$ Average wages shot up by 18 and 16 percent, in 2001 and 2005, respectively; average pensions exhibited similar peaks of 26 and 22 percent (Nikolyuk, 2006a). Non-election-year changes in wages and pensions typically exhibited low but positive rates of growth (single digits) or negative rates.
} 
Table 2. What are the Most Acute Problems Faced by the Country and Its Citizens?a

\begin{tabular}{lcc}
\hline \hline \multicolumn{1}{c}{ Problem } & June 2004 & June 2006 \\
\hline Price hikes & 73.2 & 60.1 \\
Unemployment & 49.7 & 37.0 \\
Corruption, bribes & 35.6 & 27.6 \\
Overcoming consequences of Chernobyl' & 21.1 & 25.5 \\
Crime & 37.3 & 23.2 \\
Lack of law and order & 32.9 & 22.1 \\
Violation of human rights & 30.4 & 22.1 \\
Depopulation & 19.8 & 21.9 \\
Pauperization & 58.0 & 19.5 \\
Decline in production & 22.2 & 18.7 \\
Threat posed by the West & 7.7 & 18.2 \\
International isolation & 14.7 & 14.4 \\
Decline in national culture & 13.8 & 10.8 \\
Threat of losing national independence & 7.2 & 8.3 \\
Divisions in society & 8.9 & 7.3 \\
\hline
\end{tabular}

aPercentage of responses pointing to each problem as "most acute" (more than one answer is possible). Source: Nikolyuk, 2006c and national surveys of the IISEPS; $N=$ nearly 1500 randomly sampled respondents; sample error is within the range of 3 percent.

Table 3. Time Series of Responses to the Question "If the Position of President of Belarus and Russia Were Instituted, Whom Would You Rather Vote For in the Corresponding Election?" (in percent of all responses)

\begin{tabular}{lrrrrrrrrrr}
\hline \multicolumn{1}{c}{ Option } & $11 / 99$ & $04 / 00$ & $04 / 01$ & $04 / 02$ & $12 / 02$ & $09 / 03$ & $03 / 04$ & $11 / 04$ & $09 / 05$ & $12 / 05$ \\
\hline Lukashenka & 31.0 & 22.3 & 24.4 & 14.0 & 20.5 & 21.1 & 28.7 & 29.8 & 33.2 & 38.8 \\
Putin & 13.2 & 31.1 & 40.3 & 50.5 & 46.9 & 45.2 & 35.9 & 24.3 & 25.7 & 19.8 \\
\hline
\end{tabular}

Source: Compiled by author from national surveys by the IISEPS, and Drakokhrust, 2006.

It would be reasonable to assume that a certain time lag exists between actual improvements and their effect on public opinion, which is why one can consider the June 2004 survey (Table 2) as a reflection of the 2002-2003 period when wages and pensions were stagnant. ${ }^{14}$ As for the 2006 survey, it reflects attitudes that took shape throughout 2004 and 2005 when salaries and pensions rose.

"Buying" the people's vote is but a part of the story. First, the growth in salaries and pensions would not have been possible but for the uninterrupted economic growth of Belarus since 1996. ${ }^{15}$ A World Bank (2005) team observed that "economic growth in Belarus has been genuine and robust, especially in recent years." Belarus is the only CIS country whose GNP in 2004 exceeded its GNP in 1991 by 40 percent (ibid.). And one finds no income disparities such as those in Russia or Ukraine, the two countries to which Belarusians tend to

\footnotetext{
${ }^{14}$ Average wages and pensions each decreased by 1 percent in 2002, and increased by 2 percent in 2003 (Nikolyuk, 2006a).

${ }^{15}$ From 2001 to 2005 , annual growth was between 8 and 11 percent.
} 
compare themselves. The 2005 country report of the IMF depicts economic growth in Belarus as socially equitable. "Bolstered by rapid real wage growth policies as well as decelerating inflation, consumption continued its rapid rise" (IMF, 2005, p. 2). In a national economy where the private sector accounts for just 25 percent of economic output (ibid, p. 4) and 47 percent of total employment (Ministerstvo, 2005) much of salary dynamics cannot but be interpreted as a success largely achieved through government efforts. It is then little wonder that in June 2006, 60.6 percent of Belarusians thought that under current leadership, further significant improvement of living conditions was possible, and 56.9 percent believed that the country was on the right track. Interestingly, in late 2002, only 26.6 percent of Belarusians held such views (Pozniak, 2006).

Second, although Belarusians did indicate that they value the economy over independence, they have definitely warmed up to the latter as well. In December 2005, only 12 percent of surveyed Belarusians opted for Belarus and Russia becoming one state, whereas just two years prior to that, twice as many supported the merger (Drakokhrust, 2006).

Third, to an ever-increasing extent Belarusians associate their separate-from-Russia existence with Alexander Lukashenka. Even experts who are the least sympathetic to the president of Belarus come to that conclusion. "My friends in Belorussia hate it when I tell them that Lukashenka has become the true father of Belorussian independence, . . . as during the years of his rule, the national identity which simply had not existed developed amongst both rank-and-file and the elite" (Piontkovskiy, 2006), stated one of the most avowedly proWestern Russian analysts and a frequent guest of American think tanks.

Not long ago, however, even Belarusians with warm feelings toward Lukashenka used to like Vladimir Putin better. To the question, "If the position of President of Belarus-andRussia were instituted, whom would you rather vote for in the corresponding election?" most people formerly responded "for Putin." This began to change (Table 3) after the memorable February 19, 2004 suspension of the inflow of Russia's natural gas to Belarus. This change should be attributed to a propaganda campaign directed squarely against the political establishment of Russia and to the replacement of newscasts broadcast from Moscow via major Russian TV channels by newscasts produced in Minsk.

In summary, to anyone versed in developments in Belarus, the prospects of a Lukashenka landslide in the 2006 presidential election appeared certain. Indeed, a national survey conducted in early March 2006 by VTSIOM, a Russian polling firm, showed that 60 percent of Belarusians were willing to vote for Lukashenka, 11 percent for Milinkevich, and 5 percent for Kazulin (Kirillov, 2006a). Olga Abramova, the only Belarusian MP who allows herself to publicly criticize some of Lukashenka's policies, said 11 days prior to the elections that in her judgment the range of the president's support had been steadily within 60-63 percent, whereas 25-30 percent of the electorate disagreed with Lukashenka (and that latter range also included those voting against all candidates). If the turnout were to reach 80 percent, Abramova predicted, then Lukashenka would probably win 75 percent of the vote, owing to the fact that his electorate is more committed and disciplined than that of his opponents (Kirillov, 2006b).

In hindsight, the most impressive forecast was issued by Alyaksandr Potupa, Chairman of Belarus's Union of Entrepreneurs. In a September 14, 2005 interview with the Latvian Russian-language newspaper Telegraf, Potupa indicated that "in 2006, Lukashenka's victory is as assured as it was in 2001 . He will win no less than 80 percent of the vote. But one has to understand that he would win 2:1 [or about two-thirds of the vote] even without sneaky fiddling technologies" (Martovskaya, 2005). "There is no indication at all," Potupa also said, "that the actual split of the electorate goes beyond 1:6 or even 1:7 (ibid.)" As will become 
Table 4. 2006 Presidential Elections in Belarus

\begin{tabular}{lcccc}
\hline \hline & $\begin{array}{c}\text { 03/19/2006, } \\
\text { official count }\end{array}$ & $\begin{array}{c}\text { 02/10-02/20/2006, } \\
\text { IISEPS poll }\end{array}$ & $\begin{array}{c}\text { 03/27-04/06/2006, } \\
\text { IISEPS poll }\end{array}$ & $\begin{array}{c}\text { 04 16-04/29/2006, } \\
\text { IISEPS poll }\end{array}$ \\
\hline Lukashenka & 83.0 & 64.7 & 64.9 & 63.1 \\
Milinkevich & 6.1 & 18.3 & 21.4 & 18.8 \\
Kazulin & 2.2 & 7.0 & 5.0 & 7.3 \\
Gaidukevich $^{\mathrm{a}}$ & 3.5 & 5.0 & 2.2 & 5.2 \\
\hline
\end{tabular}

aGaidukevich is a comical political figure representing what was initially the Belarusian arm of Russia's Liberal Democratic Party. The latter, as many allege, also is led by a comical figure (Vladimir Zhirinovsky), but of much higher visibility and caliber than his Belarusian clone.

Sources: Compiled by author from http://www.iiseps.org/4-06-7.html; Okonchatel'nyye, 2006.

clear from what follows, Potupa's forecast proved impeccable not only in terms of the official count (Table 4) but also, most probably, in terms of the extent of distortion of the vote actually cast.

\section{AFTERMATH OF THE ELECTION}

Throughout the elections and in the aftermath, one of the best sources of information and dialogue about the events in Minsk has been the Belarusian Service of Radio Liberty (BS $\mathrm{RL}$ ). While in hindsight some of the opinions reported by BS RL seem overly emotional and more than tinged by wishful thinking, many have withstood the test of time. For example, on March 21, 2006, in response to a question about differences and parallels between the Belarusian 2006 and Ukrainian 2004-2005 elections, Jan Maksymyuk, a Prague-based political analyst and ethnic Belarusian, had this to say: "The situation [in Belarus] is psychologically different because in 2004 people in Kiev were convinced: Yushchenko won the elections, but the victory was stolen from him. The situation of Milinkevich is different. Naturally, the results were falsified, and nobody doubts this. But at the same time, people have a feeling that Milinkevich would not have been able to win these elections even if they were honest and free" (Struve, 2006).

Viktar Ivashkevich, deputy chairman of the Belarusian Popular Front, stated that "those 83 percent infuriated everybody. People would have agreed if they had been told that Lukashenka won 55-60 percent, but 83 percent revealed that those in power do not take people seriously and just lie" (Yakoye palitychnaye, 2006). What is indeed revealing in this statement is the de facto admission that Lukashenka would have won the elections even without falsification.

Because the extent of election fraud remained unclear and open to speculation, it would make sense to resort to the results of three national polls conducted by the IISEPS before and after the elections. The results of the first post-election poll (March 27-April 6), first made public on April 20 at a meeting in the British Embassy in Minsk, were not to the liking of either the government or the opposition. Following the announcement, the results, obtained through face-to-face interviews of 1496 randomly selected Belarusian adults, showed that 64.9 percent of those polled voted for Lukashenka, 21.4 percent for Milinkevich, and 5.0 percent for Kazulin (Table 4). Because these results were called into question by many in the opposition, another national poll was conducted from April 16-29, 2006. For this second post-election survey, a different random sample of the same size was probed by a different 
group of face-to-face interviewers. The second post-election poll yielded results similar to the first. This fact, along with a sample error within 3 percent, and most importantly, the reputation of the polling firm, make these results trustworthy. They also agree with the abovementioned pre-election polling by the IISEPS (Table 4) and by the Russian firm VTsIOM and with various other pre-election forecasts. Yet some opposition-minded analysts continued to doubt the validity of those surveys, arguing that in a country run by a dictator no survey is reliable, as people are afraid to betray their views (Polesskiy, 2006).

\section{HOW RELIABLE ARE OPINION POLLS?}

Because the poll-faulting argument is advanced from time to time, it makes sense to analyze its logic and function in light of known facts about Belarus as well as the national surveys conducted there.

The logic of the argument rests on the presumption that because "we all know" that Belarus is a dictatorship, ordinary people should be afraid to openly express their opinions by implication. Like any preconceived notion, this one is hard to dispute. Most well-informed Belarus-watchers not sympathetic or beholden to Lukashenka effectively call the dictatorial nature of the Belarusian regime into question, ${ }^{16}$ but even this fact does not come across as a strong counterargument.

Functionally, the argument purports to trivialize or downright eliminate a rich source of data about contemporary Belarus by declaring these data unfit. In my view, the thesis in question is advanced either by (a) those whose knowledge of Belarus comes from media, rather than personal exposure; or (b) those who may know Belarus well enough, but sense that any mass opinions recorded by national surveys in that country that contradict their views are not to be believed.

In the end, the poll-faulting argument does not withstand scrutiny. Although Lukashenka's popularity ratings are high, they are not sky-high: $30-40$ percent of respondents probed in various surveys do not support him, and about 20 percent reveal that they voted for Milinkevich and Kazulin. Such people are too numerous to be considered heroes who have managed to overcome paralyzing fear. In Belarus, the sociologist Andrey Vardomatskiy studied the influence of fear on responses to face-to-face interviews. Based on his 1999 research, Vardomatskiy claimed that fearful respondents tend to refrain from definitive answers and therefore become a statistic in the "don't know" category. It is, however, rare that a person who does not support the president would claim that he/she is supportive of him out of fear (Vardomatskiy, 2000). In 2001, the same expert claimed that fear could artificially boost numbers of support for Lukashenka by 6 to 9 percent (Po dannym, 2001). But in 2006, in an interview with Russia's Kommersant, Vardomatskiy related that because now Belarusians are content with the material quality of life, they are more than ever willing to overcome their fear, which is therefore not likely to affect election results (Panyushkin, 2006).

Perhaps the most important argument in favor of the IISEPS and other independent national surveys in Belarus is the attitude toward Lukashenka revealed by those surveys. More specifically, the attitude toward Lukashenka correlates with other opinions not rigidly

${ }^{16}$ Some authors who called into question the notion that Belarus is a dictatorship include David Marples, Heinz Zimmermann, Elena Gapova, and Yaroslaw Shimov. As stated on behalf of the entire group of authors of the compilation Contemporary Belarus, "The consensus of this volume is that [Belarus] is not a total dictatorship, since it retains some aspects of a democratic state, but that it could be described as an 'elected dictatorship"' (Korosteleva et al, 2003, p. 16). 
connected with political loyalty. Thus, Lukashenka supporters dislike entrepreneurs and the West, prefer state-owned enterprises, and value low but steady over high but unsteady earnings. If the basic reason behind their ostensible support of Lukashenka were fear, then in response to all the other questions that are definitely not frightening, the "fake" Lukashenka devotees would likely be expressing their true opinions: pro-European, liberal, and promarket. The fact that Lukashenka supporters do not identify with those opinions means that they vote for Lukashenka because he personifies their values, namely attachment to economic security, dependency on the state, risk-aversion, distrust of private business, etc.

The theory that people under the authoritarian regimes hide their opinions also contradicts the experience of "orange revolutions." Thus, in Ukraine, mass dissatisfaction with the institutions of power had been recorded by sociological surveys (including Gallup polls) well before the 2004 elections. According to a national survey conducted in Serbia in September 2000, Kostunica enjoyed the support of 24 percent of all adults, compared with 18 percent for Milosevic (Center for Political, 2001). In both cases, change at the helm of power was accurately predicted by the sociologists. While in Belarus, dissatisfaction with the government is widespread, the numerical gap between Lukashenka supporters and those of, say, Milinkevich is simply too large.

\section{ARE BELARUSIANS POORLY INFORMED?}

A somewhat softer argument is often advanced as well. Yes, the surveys are accurate, but Belarusians are poorly informed because Belarus is isolated, and independent media are harassed. This argument has some merit but its actual significance can be assessed if one takes into account how and why people in Belarus and elsewhere acquire information. The fact that Belarus's government mistreats independent media cannot be denied. As an example one need only mention the Belorusskaya delovaya gazeta, for many years a popular Russian-language outlet for opposition-minded views. In March 2006, it had to discontinue its print edition because the state denied it access to distribution outlets and to a printing press. In September 2006, the Arche, a Belarusian-language journal, was suspended for three months because it allegedly overstepped its status as a cultural and historical periodical by publishing political articles. Considering that the Arche had a circulation of 900 copies and only 400 subscribers (of which many were foreigners), the government's vigilance may be considered excessive.

At the same time, however, Belarusians travel abroad at least as (and possibly more) frequently than Americans, only 21 percent of whom have passports (Americans, 2005). According to available surveys, 16 percent of Belarusian adults have visited just two foreign countries - Poland (11.4 percent) and Germany (4.7 percent) — over the past five recent years (IISEPS, 2005). The authorities cannot prevent one from listening to the BS RL if one prefers Belarusian or the Deutsche Welle if one prefers Russian. The EuroNews (in Russian) is a TV channel many Belarusians have in their homes. Also readily available is RTVI, a television channel owned by the Russian rogue oligarch, Vladimir Gusinskiy. In the western half of Belarus, Polish television channels, highly critical of Lukashenka, can be viewed without a problem. While individual Internet access in Belarus is limited, it is expanding rapidly, and many young people browse the web in public libraries and internet cafes. Such opposition newspapers as Narodnaya volya, Salidarnasts, Belorusy i rynok, Tovarishch, and Belorusskaya hazeta continue to publish and can be easily obtained.

Aside from the existence of outlets presenting alternative views, the willingness to obtain those views should be considered. Svetlana Alexievich describes how in a small 
Belarusian town an opposition newspaper was being passed out free of charge. In that newspaper, the disappearances of independent politicians and journalists were described. Throughout an hour no more than five people approached the man with a stack of papers. Some picked it up and ... returned it. "This was not so much about fear," said Alexievich. "People were just not interested" (Alexievich, 2006).

If and when, however, people are interested, the situation is different. In July 2006, Sergey Nikolyuk probed the extent to which Belarusians were informed about Russian Gazprom's plan to significantly raise the price of natural gas sold to Belarus and the extent to which they believed that Gazprom's intention was going to materialize. By the time of the probe, the official Belarusian media had mentioned the issue only in passing, and a couple of articles in the Belarus Segodnya dispelled speculation about the price hike, as the negotiations were still under way, and the political leaders of Russia would (reportedly) not allow such a price hike to pass. Nikolyuk's probe not only ascertained that the overwhelming majority of Belarusians knew about Gazprom's intent but also - contrary to the stand taken by the official press - believed that this intent was going to be realized (Nikolyuk, 2006b).

Belarusians are thus reasonably well informed about issues that concern them. Access to information is not a supply-side problem in Belarus, but rather a function of one's interest and willingness to obtain information.

\section{THE NEW OPPOSITION AND LUKASHENKA'S POPULARITY IN RUSSIA}

When it became clear after the election how few Belarusians supported the opposition and how many genuinely believed that life is improving under the current regime, the opposition plunged into post-election depression. "The feeling of hopelessness begins to sink into the most tenaciously optimistic mindset," observed Vital Silitski (2006). Silitski, together with Andrey Dyn'ko, Valer Bulgakau, and Igar Babkou, is part of the new wave of Belarusianspeaking nativist ideologues who have replaced the old guard led by Zianon Pazniak. No less dedicated to battle against Russia's cultural colonialism, they are more tolerant, intellectual, scholarly, and versed in foreign languages. Apparently they are also able to accept defeat without resorting to wild-eyed exaggerations and conspiracy theories (Pazniak signatures). "The Lukashenka regime," writes Silitski, "has managed to achieve a certain equilibrium between itself and society by ... placing the outlook and political culture of the average Belarusian into its (regime's) own foundation" (ibid., emphasis added). Moreover, "the events on the Kalinovsky Square reflected the mobilization potential of an illusion," 17 as no action of the opposition could bring about political change in Belarus at this point in time. "The society objectively recognized the Lukashenka victory in 2006" (ibid.).

A consensus is emerging among the opposition that the regime has consolidated and broadened its social base (Matskevich, 2006). Lukashenka's support is growing particularly among Belarusian youth, a demographic with which the regime has not heretofore been especially successful. Vladimir Matskevich, a fierce critic of Lukashenka, observes that "Belarusian youths now beginning to support the regime are proud that respect and

${ }^{17}$ Following the elections, dozens of youths set up tents on the Oktyabrskaya (Russian) or Kastrychninskaya (Belarusian) Square in an attempt to reproduce the events of the Orange Revolution in Kyiv. The vigil in Minsk lasted from March 19 to 24 when it was forcibly dispersed by police; the youths received 15-day jail sentences (see Chivers, 2006). During the vigil, the protesters referred to the square as ploshcha Kalinovskaha (Kalinovsky Square) in honor of Kastus Kalinovsky, a cult figure in the pantheon of nationally conscious Belarusians. 
[favorable] attitude were not just bestowed upon Belarus (as Bill Clinton did upon Stanislaw Shushkevich) but have been earned or won in a fight. This is what makes this regime genuinely Belarusian in many people's eyes, a kind of leadership that nationalists dreamed about during their heyday in the early 1990s" (Matskevich, 2006).

Outside of Belarus, Lukashenka's strongest support base is in Russia. On March 20, just one day after the Belarusian elections, Ekho Moskvy, a Moscow-based radio station known for its liberal and pro-Western views, conducted its usual three-person debate, this time devoted to the previous day's elections in Minsk. During the show, the radio conducted a survey, polling listeners regarding who they would rather have as president of the would-be Belarus-Russia union, Vladimir Putin or Alyaksandr Lukashenka. Two telephone numbers were given to those willing to register their responses. More than 6,000 people called, which by the anchorwoman's admission, was an unusually high number for an evening show that lasted one hour and 20 minutes. Eighty-two percent of callers preferred Lukashenka versus 18 percent who preferred Putin (Vybory, 2006). While one should perhaps not make too much of a "non-scientific" poll such as this, shrugging it off entirely would be even more mistaken. Lukashenka is not only popular in Belarus; he is wildly popular in Russia.

After the announcement in June 2006 that Vladimir Putin would once again (for the fourth time) field questions of Russian citizens and foreigners on TV, Yandex (a Russian Internet portal) published the most popular questions on all topics, including Russia's relations with Belarus. Altogether, 1207 questions were received on that topic. The most popular question, one with which 637 people identified, read: “Aren't you (Russia) entertaining the idea of joining the Republic of Belarus and ceding power to Lukashenka, our best in the world president? It is obvious that nobody but him is able to put Russia, which is decaying and living in poverty and hunger, in order. Why are you performing a job you were not cut out to do? Only Lukashenka will rescue Russia from world imperialism and from the decaying West!!!" To be sure, the second most popular question, supported by 450 people, was "Why are you supporting the Belarusian dictator?" (Voprosy Prezidentu, 2006).

Eliciting extreme reactions is indeed a signature trait of the current Belarusian leader. People either love or hate him, with few intermediate emotions. For this reason, a soberminded analysis of Lukashenka's presidency that avoids preconceived notions of any kind is long overdue. To accomplish this, Lukashenka should be viewed in the context of Belarusian history and identity, not simply as leader personifying a type of political order ("dictatorship") imposed on poorly informed people whom better positioned outsiders ought to enlighten and liberate. More specifically, one promising analytical approach would be to identify Lukashenka and his policies with a certain "national project" of Belarus-a corpus of normative ideas about the past, present, and future of that country.

\section{BETWEEN RUSSIA AND POLAND: THE NATIONAL PROJECTS OF BELARUS}

The Belarusian national idea was first packaged for popular consumption at the very beginning of the $20^{\text {th }}$ century. Prior to that and for some time thereafter, most Belarusians identified themselves as tuteishiya (locals). As they became more educated and moved up the social ranks, they used to cling to either Russians or Poles, who belonged and perhaps still belong on opposite sides of what Samuel Huntington has called a civilizational fault line, a cultural divide that runs across Belarus. Joining hands across a divide of that kind has always been difficult, and many locals have preferred to choose one side or the other. On the basis of his inquiry into archival materials, Theodore Weeks (2003) demonstrated vividly the torment 
of some local intellectuals (e.g., Ferdinand Senchikovski) in the early 1860s when they were forced to choose between Poles or Russians, and - having made their choice - they sometimes changed their mind. That was then. Now, according to Igar Babkou (2005), choosing sides is not a worthwhile pursuit because any version of Belarusian identity that will prove to be inclusive cannot but be trans-cultural. This view is worthy of consideration, as it has to do with the greatest challenge that Belarus faces, that of national consolidation across the cultural divide. Regrettably, few influential public opinion leaders in Belarus have been up to this challenge.

Shortly after it emerged, the Belarusian idea forked down the old division line. On the one hand, a historical tradition emerged that cast Belarusians as an inherently Western community, the descendants of the Great Duchy of Lithuania. The other tradition, older than the Belarusian idea itself, was West-Rusism, a theory that emphasized Belarusian peculiarity, but only within the confines of the Russian cultural universe. Among those who embraced this alternative tradition was Yauchim (Yevfimii) Karsky, the most reputable Belarusian linguist of all time. ${ }^{18}$ Needless to say, most historical accounts of Belarus published under the Soviets embrace the view that Belarusians constitute one prong in a three-prong Russian ethnicity that gave rise to three East Slavic nationalities interrelated closely, almost to the point that reders their differences unworthy of serious discussion. And the greatest common experience that solidified the bond was the Great Patriotic War of 1941-1945.

Until recently, these were the only two national projects of Belarus, referred to by some as the Nativist/pro-European and Muscovite Liberal (or Russophile) projects. To confuse matters further, today there seem to be three national projects, as some Belarusian analysts (e.g., Bulgakau, 2001; Abushenka, 2004; Babkou, 2005) have shrewdly added "Creole nationalism" to the equation. ${ }^{19}$ They would not have been able to do this without Mykola Rabchuk (2000), who (in his research on neighboring Ukraine) repeatedly called into question dichotomies like Russians-Ukrainians, Ukrainian speakers-Russian speakers, and nationally conscious-mankurts (i.e., people without memory) and proposed one of the most conceptually fertile ideas in the field of post-Soviet nation-building - the idea of Creole nationalism. It turns out that many Belarusians who speak trasianka are quite patriotic and nationalistic. As described by Uladzimer Abushenka (2004), these people are at an intermediate stage in their socio-cultural evolution. For them, things Russian no longer belong in "we," but cannot yet be assigned to "they." Similar ambiguity typifies their attitude toward things Belarusian.

It is now tempting to "assign" the three major candidates in the 2006 Belarusian presidential election-Milinkevich, Kazulin, and Lukashenka - to each of the three projectsNativist, Muscovite Liberal, and Creole (henceforth Projects One, Two, and Three), respectively. Of those three personalities, perhaps only Kazulin does not come across as a mainstream representative of "his" alleged (Muscovite Liberal) constituency. Project Two, however, is the least cohesive of the three, and so with some qualifications Kazulin probably fits, while both Lukashenka and Milinkevich clearly epitomize their respective constituencies.

Consequently, it is equally tempting (though equally debatable) to interpret the showing of these three presidential hopefuls in the March 2006 elections as an indication of the relative

\footnotetext{
${ }^{18}$ Incidentally Karsky, a pure ethnographic Belarusian, as he introduced himself, was from 1905-1915 rector of the Warsaw University and was reportedly one of the most ardent Russifiers of Poland, not just Belarus.

${ }^{19} \mathrm{~A}$ more consistent description of each project, as well as an outline of their strengths and weaknesses, can be found elsewhere (Ioffe, 2007).
} 
influence of the national projects in Belarus. As a measure of "showing," the results of two post-election surveys by the IISEPS (2006) are more appropriate than the officially announced electoral outcome. Estimated by those polls, Lukashenka's support is in the vicinity of 64 percent, Milinkevich's within the 18-21 percent range, and Kazulin's about 5-7 percent (Table 4).

Lukashenka can speak on behalf of roughly two-thirds of Belarusians because he and they agree on some critical issues defining Belarus as a country and Belarusians as a community. To better understand the character of the bond between Lukashenka and many Belarusians, two features of Belarus should be invoked. Belarus is a country of delayed urbanization and it is a country with much-delayed nation-building. From this dual perspective one sees that: (1) Lukashenka is a person of humble origin and peasant upbringing, as are many Belarusians; (2) most Belarusians either speak trasianka themselves or have/had parents who do/did, and so does Lukashenka; (3) most Belarusians have found it problematic to see themselves as a community apart from Russia, and so has Lukashenka. Yet the country and its leader have made important steps in the direction of psychological (albeit not yet economic) independence from Russia. Significantly, they have done this in unison, without any attempt on the part of the leader to push it along, get ahead of his fellow countrymen, or preach historical myths that do not strike a chord with Belarusians. While Lukashenka's charisma appeals to Belarusians, so do his policies, particularly his emphasis on communalism, a social safety net, and on eschewing privatization, Russian and Ukrainian style. With his policies and Russian energy supplies at a discounted price, ${ }^{20}$ he managed to deliver $8-11$ percent economic growth annually since 2001 and significantly boost real wages. Nowhere in the world do leaders who accomplish this get ousted, unless a well-established democratic system with term limits is firmly in place. ${ }^{21}$

The multiplicity of national projects as well as the fact that most Belarusians identify with the project whose very nature involves transition from a pre-national to a national existence reflect a fairly early stage of nation-building that is truly unique in Europe and invokes parallels instead with sub-Saharan Africa. A situation like this cannot but have some collateral effects. For example, according to the surveys conducted in early 2006 by the agency Eurasian Monitoring, 47.5 percent of those probed in Belarus are entirely unworried about the possible loss of national distinctiveness and traditions. For comparison, only 28.2 percent of respondents in Russia and 33 percent of Ukrainians are in that category (Kirillov, 2005). If you do not have a clear idea of what it is that you have or may have, you do not worry about losing it. If, as seems likely, Belarusians are not yet a fully fledged nation, what are the likely paths that lead to full nationhood? According to the historian Zakhar Shybeka (2006), it can be achieved: (a) on the basis of the tradition that goes back to the Great Duchy of Lithuania, Nasha Niva, and BNR (i.e., on the basis of what has been defined as Project One); or (b) on

${ }^{20}$ The foundation for Belarusian economic growth provided by cheap energy imports from Russia appears to have weakened considerably in late 2006. After a dispute between Belarusian authorities and the Russian gas monopoly Gazprom over prices for Belarusian gas imports, a five-year agreement on January 1, 2007 raised prices from $\$ 46$ per thousand cubic meters (tcm) to $\$ 100$ in 2007 , with provision that they increase steadily to the level paid by EU countries by 2001 (Myers, 2007a). Oil shipments along the Druzhba pipeline through the republic were halted shortly thereafter, after Russia imposed a special duty of $\$ 180$ per ton of oil shipped to Belarus, and the latter announced a $\$ 45$ per ton transit fee on oil moved through the republic to customers farther west in Europe (Myers, 2007b). Although the latter (transit fee) appears to have been rescinded as part of an agreement purportedly ending the dispute, it was announced on February 5 of this year that Belarus planned to increase these fees by 35 percent in mid-February 2007 (New Pipeline, 2007).

${ }^{21}$ Even George Krol, former American ambassador to Belarus, whose term ended in late July 2006, stated in his last interview (in his ambassador's capacity): "I consider Lukashenka a talented politician, a politician by nature. . . . He very well understands a segment of the Belarusian people. He exudes a specific charm" (Ambasador, 2006). 
the basis of "Russian provincialism, which goes back to the BSSR" (Shybeka, 2006), that is, to Creole identity. The first of these tracks would be faster and more organic, according to Shybeka, but "even the second track is not a blind alley at all; it may take longer but it is not futile (ibid.)."

Because many more Belarusians effectively adhere to Creole than to any other identity, I will begin sorting out new developments in the area of Belarusian nationalism from Project Three. In this area, two developments deserve attention: (1) new texts devoted to the socalled "national ideology" of the Republic of Belarus, a peculiar intellectual product that I have defined as a brainchild of Creole nationalism (Ioffe, 2007); and (2) the rapidly declining popularity of neoliberal (economic) ideology in post-communist discourse.

\section{NEW NATIONALIST NARRATIVES OF PROJECT THREE}

Authored by Anatoly Rubinov, deputy chief of the Presidential Administration, a programmatic text on ideology appeared in July 2006 (Rubinov, 2006). According to Rubinov, the Republic of Belarus is the first independent Belarusian state ever. Because history is continuous, this state succeeds its immediate predecessor, the BSSR, which in turn owes its emergence to the 1917 Communist Revolution and the Soviet Union, within which the BSSR was an economic success story. That means that the notion of Revival (Adradzhennye), a major catchword of the nativist ideology popular in the early 1990s, is false. "What is there to revive?" exclaims Rubinov. "Poverty, deprivation, illiteracy so vividly described by Janka Kupala in his classic works? Or perhaps even earlier times of bondage? And yet the idea of Revival has already become a kind of cliché" (ibid.).

In a comment to Rubinov's article, Boris Lepeshko, deputy rector of Brest State University, went further. "Many lances have been broken over the national idea. If, however, that idea has not crystallized to this day, it means that it is . . stillborn. The national idea is not indispensable for a state, after all" (Lepeshko, 2006). Lepeshko also asserted that "it does not make sense to try to unify all people by one ideology; rather one should talk about the practicality of one specific form of ideology that the state is applying now" (ibid.). This bringing down of a needlessly high-minded notion of ideology echoes the musings of Yuriy Shevtsov (2005, p. 72), to whom "Belarusianness is . . a technology of living in this specific region; [and] sometimes it is the technology of survival."

Alyaksandr Feduta, who analyzed seven 2004-2006 books devoted to the Belarusian national ideology, was struck by the lack of clarity in defining it. Perhaps its most tangible aspects, as depicted by some ideologues, are "emphasizing communal-collectivist (Eurasian), not individualistic (West European) values" (Feduta, 2006a) and a geopolitical leaning toward Russia due to the pull of both Russia's high culture and its energy resources. According to one of those national ideology books, "a strategic unhooking of Belarus from Russia" would be "tantamount to the rejection by the Belarusians of their civilizational identity" (ibid.).

Persistent appeals to Belarus's Soviet history while failing to discern anything genuinely Belarusian in earlier times seems to be a pitfall for Creole nationalism. But if the problem of Belarusian historical self-perception within the Creole project is self-effacing closeness to Russia, it is intriguing to see how Russia, in a way, lends its "helping hand" by pushing Belarus aside from time to time. Disassociating Belarus from Russia gets easier each time Russia threatens to stop subsidizing the Belarusian economy by supplying cheap natural gas. February 19, 2004, was a particular hallmark in this regard. After Gazprom discontinued the flow of gas into Belarus for several hours to force that country to pay off its energy debt, I 
visited Lukashenka's website [www.//president.gov.by] and counted 18 questions from Belarusians (out of a total of 43 questions published on that site) with a pronounced antiRussian streak. For example: "Why should we unite with Russia that fights wars all the time and cannot put its own house in order? Do we need terrorist attacks and war? We ought to stick to our own independent way. What do you think?" At this writing (February 2007) we are witnessing yet another increase of tension between Belarus and Russia over a scheduled rise in the price of natural gas by a factor of two or more (see note 20 above). Here again Lukashenka's rhetoric portrays Belarus as an innocent victim of the mercenary and rentseeking behavior of Russia's tycoons, who are inseparable from Russia's political establishment. "Did you hear that they offered us to buy gas at a higher price than Germany?" Lukashenka exclaimed at a press conference for Russian provincial journalists. "Fifty years ago, this would have been unthinkable. But the generation that fought in the same trenches [with Russians] is not yet entirely gone" (Lukashenka, 2006). This proved an effective way to rally Belarusians around their leader and to mentally detach them from a hostile Russia at the same time.

During recent negotiations between Russia and Belarus about the price of natural gas (December 2006) and then about export tariffs on crude and refined oil (January 2007), Lukashenka reinforced his symbolic capital as a Belarusian nationalist even more. For the first time, the official Belarusian media put it plainly: Belarusian independence is at stake, and it is President of Belarus, not by any means the Belarusian-speaking opposition, who is defending the statehood of Belarus. The editorials in Belarus Segodnya (e.g., Yakubovich, 2007) did not mince words. Also, on several occasions, Lukashenka's own rhetoric was full of meaning. For example, on December 29, 2006 during a visit to the town of Zhlobin, he exclaimed: "Today I instructed the Prime Minister to get in touch with the government of Russia and tell them that we will rather live in dugouts than succumb to their blackmail!" (Lukashenko: V zemlyanki, 2006).22

Another important way in which the Belarusian ruling elite is distancing itself from Russia is by criticizing the neo-liberal model of Russia's post-1991 development, which has brought about income stratification on a scale not experienced and not desired by Belarus. The profound dissatisfaction of many Poles with the newly acquired peripheral status of their country within the European Union also helps the Lukashenka team to justify its own course, because Poland was an early patient of the so-called "shock therapy." 23

"The irony of the West preaching civil society and shock therapy at the same time is that you cannot have both," writes Mark Almond (2006), an Oxford University lecturer in modern history. "Western advisers made economic transformation a priority, but wherever their advice was followed it was poverty, not pluralism that resulted. Across the old communist block "shock therapy" enriched a few dozen oligarchs and their foreign economic advisers, but the mass unemployment it caused and the collapse of public spending it demanded smashed the foundations of the civil society emerging under Gorbachev." Almond caused a stir by suggesting that "by protecting Belarus from ravages of free-market fundamentalists and delivering economic growth ... for the masses of Belarusians, Lukashenka has sown seeds of a pluralistic society far better than by handing the state's assets over to half a dozen cronies of western advisers" (ibid.). An analysis of the recent dynamics of personal consumption in Belarus by

\footnotetext{
${ }^{22}$ It should be noted that Belarusians are proud of their partisan activities during the 1941-1944 German military occupation, when many partisans lived in such earthen structures (zemlyanki).

${ }^{23}$ For background, see Feakins and Białasiewicz (2006).
} 
the economist Leonid Zayiko, a frequent Lukashenka-basher, effectively upholds Almond's view. Personal incomes in Belarus have been growing at a rapid pace, and "with growing income we will be also demanding political wares of higher quality" (Zayiko, 2006). In other words, favorable political change in Belarus is now viewed as resulting from the current regime's economic success, not from overt democracy promotion.

In this regard, one aspect of the aforementioned ideological treatise by Rubinov is noteworthy, as it appeals to the experience of Europe's welfare states: "We are not copying what Sweden and Austria do and not because we think that they do not fare well. We know that they do. But it is not possible to transfer their experiences to us directly and immediately because our tradition, mentality, and economic base are too different" (Rubinov, 2006). Several lines further down, a more focused view on these differences can be found: "The Western system was being built for centuries ... It is not just ideology that has been instrumental in it, it is a certain level of civilization that cannot be achieved in one day or even in twothree decades (ibid.)." And because we have not yet stopped littering our forests and still tolerate filth, theft, corruption, and lack of respect for a human being, privatization would lead to chaos and destruction. Moreover, "the example of Russia vividly shows what one-time distribution of property and self-removal of the state from economic regulation lead to" (ibid.).

Those unimpressed by Rubinov's message may well be missing a point. Invoking a feature shared by Belarus and Russia he in the same breath contrives to set them apart. The shared feature is the traditional inferiority complex vis-à-vis "more cultured" (Western) Europe. What separates Belarus and Russia, according to Rubinov, is how their governments treat their respective uncivilized masses. Whereas Russian leaders appear to have recklessly overstepped the bounds of the national character, the Belarusian ruling elite have been more circumspect. As Alexander Pushkin once observed, "the government is our sole European"that is, the sole agency that effectively promotes European values despite resistance of uncultured masses.

By all accounts, Creole nationalism, Belarusian style, is on the offensive; its mobilization potential in Belarus is second to none, which appears to be more important than critical remarks about the unsophisticated nature of Lukashenka's court ideologues. On the one hand, surveys show that Russia tops the list of the friends of Belarus as perceived by ordinary Belarusians. On the other, fewer and fewer want to be incorporated into Russia, and more and more are aware of Russia's expansionist bent. According to an April 2006 national survey (Drakokhrust, 2006), 65.4 percent of Belarusians believe that Russia's leadership desires to incorporate Belarus, whereas just at the end of 2005, only 46.9 percent thought so. Moreover, 48.3 percent of Belarusians believed (in April 2006) that Russians en masse share the imperial attitude of Russia's leaders. Whereas in April 2006, 45 percent of Belarusians were in favor of a "union state" with Russia in which Belarus would nevertheless retain its own statehood, just three years ago, 57.5 percent favored this option (ibid.). Finally, whereas only 12 percent of Belarusians opted for a single-state solution with Russia in December 2005, in March 2003 as many as 25.6 percent did. "Ironically, it may be that fostering the RussiaBelarus Union may eventually help promote the pro-Western ideological blueprint for Belarus," I wrote in 2003 (Ioffe, 2003, p. 1267). "The likelihood of this outcome would increase if Belarus is somehow mistreated in that Union, which seems plausible. The only way to promote the vision of Belarus as a nation apart from Russia is through opposition to Russia's real and/or perceived actions (ibid.)." As tension grows between the two countries in early 2007 in tandem with energy-related disputes, it appears that this prediction is 
materializing, and there is poignant irony in the fact that this has no connection at all to the activity of the overtly anti-Russian-nativist group.

\section{NEW NATIONALIST NARRATIVES: PROJECTS ONE AND TWO}

Fewer and fewer ideological nativists (Project One) turn for spiritual guidance to Zianon Pazniak, for whom even Milinkevich and the Belarusian Popular Front's leader Vintsuk Viachorka are Russian agents of influence, while the entire segment of the anti-Lukashenka electorate not embracing Pazniak's views is the co-creation of Russian and German intelligence (Pazniak, 2005). Andrei Dynko, former editor of the major nativist publication (Nasha Niva), criticizes Pazniak for his contemptuous attitude toward other opposition leaders, and also faults Pazniak's comrade-in-arms, Siarhei Navumchik, for trivializing economic issues to the point of declaring them completely irrelevant until the national symbols and language gain prominence in society. "Even as a matter of rhetoric, it is not worth declaring the priority of symbols over the economy" writes Dynko (2006). Valer Bulgakau (2006), who edits another nativist publication (Arche), acknowledges that "the cost of acceptance by Belarus of a democratic model of Western type will be a prolonged economic crisis . . . and a decrease in social well-being. In order to withstand this and not roll back into authoritarianism, the society will have to demonstrate a conscious will (ibid.)." Much patience and sacrifice must be put on the altar of a nationalist and democratic future. And because Belarusians are not about to embrace the national idea [that fits Project One] soon, Belarusian intellectuals ought to be prepared for long and tedious creative work that may take several decades (Tsi magli, 2006).

Two intellectuals, Yury Drakakhrust and Alexander Feduta, whose earlier publications allow one to identify them with the core constituency of Project Two, weighed in on the issues of Belarus's self-perception and on the threat to its statehood. Drakakhrust's article in a Russian periodical invokes Valyantsyn Akudovich's earlier analysis of the Belarusians' ambivalent attitude toward their great eastern neighbor. According to Akudovich, "Russia is not to the east of Belarus - rather, Russia is the east of Belarus" (Drakokhrust, 2006). This means that the spatial continuity is inherent in Belarus's self-perception; because the ethnic frontiers have not been distinct, at least part of Russia's space has always been within Belarusians' mental map. And so has part of Poland, albeit to a lesser extent. ${ }^{24}$ From this perspective Drakakhrust interprets a peculiar relationship between the geopolitical leanings of Belarusians and their comparative assessments of quality of life revealed by a December 2005 national survey of the IISEPS. Unless one factors in the above-mentioned spatiality, the relationship reflected in Table 5 seems counterintuitive to the point of suspicion that someone has switched the two columns of the table by mistake. Indeed, according to Table 5, those believing that life in Russia is better than life in Belarus evince a stronger leaning to Europe than to Russia. Conversely, those believing that life in Belarus is better than life in Russia make a geopolitical choice in favor of Russia, not Europe. Drakakhrust's reading of this relationship is that the traditional attitude of Belarusians to Russia is not by any means

\footnotetext{
${ }^{24}$ This innate spatiality of Belarus's self-perception echoes observations of some other scholars. Thus, according to Igar Babkou, a civilizational fault line not only cuts across Belarus, but is the formative feature of a potentially inclusive form of Belarusian nationalism (Babkou, 2005). My analysis reveals a gentle spatial gradient within the fragment of the Slavic vernacular space squeezed between Polish and Russian, whereby dialects morph into one another as one proceeds east from the core area of standard Polish or west from the core area of standard Russian (Ioffe, 2003).
} 
Table 5. Relationship between Comparative Assessments of Quality of Life and Geopolitical Preferences (in percent) ${ }^{\mathrm{a}}$

\begin{tabular}{|c|c|c|}
\hline \multirow{2}{*}{ Choice between joining Russia or the EU } & \multicolumn{2}{|c|}{ Where is life better? } \\
\hline & In Belarus (67.8) & In Russia (14.7) \\
\hline Joining Russia (51.6) & 58.5 & 40.6 \\
\hline Joining the EU (24.8) & 21.1 & 38.1 \\
\hline \multicolumn{3}{|c|}{ Should Belarus join the EU? } \\
\hline Yes (36.7) & 33.3 & 56.9 \\
\hline \multicolumn{3}{|c|}{$\begin{array}{l}\text { This is a cross-referenced table compiled on the basis of a December } 2005 \text { national survey conducted by the } \\
\text { IISEPS involving a random sample of } 1500 \text { adults; sampling error is within a range of } 3 \text { percent. For example, } 58.5 \\
\text { percent of all respondents prefer joining Russia and believe that life in Belarus is better, whereas } 51.6 \text { and } 67.8 \text { per- } \\
\text { cent, respectively, responded affirmatively to each proposition independently. } \\
\text { Source: Compiled by author from Drakokhrust (2006). }\end{array}$} \\
\hline
\end{tabular}

mercenary, as the "domestic nationalists" [read "those embracing Project One"] repeatedly allege; rather it is ideological or value-laden. For those who think that life in Russia is better, Russia is to the east of Belarus; but for the majority (67 percent according to Table 5) for whom life in Belarus is better, Russia is the east of Belarus. You just cannot rid yourself of your own east, you can only try your best to make it (Russia) as good as Belarus already is.

Alyaksandr Feduta (2006), almost invariably writing in Russian, published a Belarusianlanguage appeal to the nativist community, titled "The Country of the Deaf: The Fatherland is in Peril." The appeal calls upon all Belarusian patriots to set their contradictions aside and not obstruct the would-be efforts of Lukashenka to enlist Western support in case Russia decides to incorporate Belarus, which seems increasingly likely to the author. Curiously, no nativist ideologue took Feduta's appeal seriously. "One should not identify the Fatherland with the regime," replied Bulgakau. Only those already in the same nationalist/ideological niche with Feduta responded in kind. "The irony of the situation," commented Aleksei Medvetsky (2006), "is that carried away by the struggle for Belarusian democracy one may find oneself without Belarus. Not just the authoritarian Belarus that Bulgakau is writing about—without any Belarus at all." Regrettably, even in the face of a would-be critical situation, Belarusians cannot bring themselves to speak in one voice.

\section{CONCLUSIONS}

Lukashenka's grip on power in Belarus can by no means be interpreted on the sole basis of his authoritarian style of rule, much less dictatorship. Lukashenka embodies a strand of Belarusian nationalism that is aligned with the self-perceptions, mentality, and aspirations of many ordinary Belarusians. By harnessing this sort of nationalism, the regime led by Lukashenka has achieved tangible economic success, not dampened by the social stratification that has emerged in many neighboring countries. In Belarus, most personal incomes and consumption have been increasing so rapidly that even the critics of the Lukashenka regime now admit that democratization is more likely to result from the escape from poverty than from overt democracy promotion or embracing a brand of nationalism typical of the Central and East European countries and western Ukraine. In fact, Lukashenka's ability to exploit Belarusians' cultural leanings toward Russia while opposing the incorporation of Belarus into Russia and denying Russian corporate groups access to the country's most significant 
economic assets breeds nationalism, Belarusian style, more efficiently than overt appeals to switch to the Belarusian language and "genuinely Belarusian" symbols.

Belarus is a country with an unfinished nation-building. The country's biggest challenge is overcoming a schism between three groups of nationally conscious Belarusians. It would serve Belarus best if these groups recognized each others' strengths and promoted common ground, which is already manifest in the socio-economic success of Belarus, the value of its statehood, and to some extent in the recognition of its unfinished nation-building. It is easy to see that all three national projects of Belarus possess complementary features. Obviously, Creole nationalism (Project Three) is the most popular, yet it deprives itself of the historical myths that appeal to a more sophisticated audience. Certainly the nativist variety of nationalism (Project One) has a "copyright" to such myths, but the group embracing them would do well to renounce arrogance and the idea that only one version of "Belarusianness" can be accepted. Surely Muscovite liberals (Project Two) offer a bridge between the two other projects because many have channels of communication open to both.

Western policy-makers might be best advised to downgrade the geopolitical rationale of their pronouncements on Belarus and tone down their confrontational rhetoric. Nationbuilding is the prime task for Belarus, which is why the West would be well served to promote national consolidation, not preclude it by sponsoring one minority strand (or occasionally two) of Belarusian nationalism. It is abundantly clear that Project One cannot win Belarus over to the West, no matter how generously it is funded. Western policies in regard to Lukashenka's Belarus have been strikingly ineffective, and Lukashenka is at his best when bullied and threatened, invariably winning public support under such conditions.

Once concocted, political clichés assume a life of their own and are difficult to undo. When one says that "Belarus is Europe's last dictatorship" and then repeats this statement over and over, a false sense of clarity results - a cognitive obstacle that can be cleared only through a comprehensive understanding of that country. Consequently, it may remain difficult for some Belarus-watchers to realize that the country's major predicament is not Lukashenka per se, but rather unfinished nation-building. In many ways, Lukashenka is a product of the nation-building impasse, not vice-versa. Facilitating national consolidation in Belarus thus is more in the West's interest than pitting one group of Belarusians against another. Only national consolidation, not forceful democracy promotion or confrontational rhetoric, will untether Belarus from Russia.

\section{REFERENCES}

Abushenka, Uladzimer, "Mickiewicz kak 'kreol': ot 'tuteyshikh geneologii' k geneologii tuteshastsi" (Mickiewicz as a Creole: From Genealogy of the Locals to Genealogy of Localism)," 2004 [http:/ /www.lib.by/frahmenty/sem-abuszenka.htm].

Alexievich, Svetlana, Voices from Chernobyl: Chronicle of the Future. London, UK: Aurum Press Ltd., 1999 (translation from Russian).

Alexievich, Svetlana, Voices from Chernobyl: The Oral History of a Nuclear Disaster. Champaign, IL: Dalkey Archive Press, 2005.

Alexievich, Svetlana, "Idyot tonkaya obrabotka soznaniya (A Refined Brainwashing Is Under Way), Belorusskiye novosti, October 18, 2006 [www.naviny.by].

Almond, Mark, "Less Bizarre Than It Seems: The Landslide in Belarus Reflects its Demonized Leader's Refusal to Back Market Fundamentalism," The Guardian, March 21, 2006.

Ambasador ZSHA Zhorzh Krol: "Ya sapraudy lichu Belarus utorai radzimai" (U.S. Ambassador George Krol: 'I Truly Consider Belarus to be my Second Homeland)," Belarusian Service of Radio Liberty, July 12, 2006 [www.svaboda.org]. 
"Americans Are Turning Out the World," Yale Global, November 24, 2005 [http://yaleglobal.yale.edu/ display.article?id=6553].

Babkou, Igar, "Genealyogiya Belaruskai idei (The Genealogy of the Belarusian Idea)," Arche, 3:136165, 2005.

Boichenya, Viktor, "Yedinyy: politicheskiy portret (The Single [Opposition Candidate]: A Political Portrait)," Belorusskaya Delovaya Gazeta, March 7, 2006.

Bolonskaya, Yanina, "Nezakazannye tsifry" (Statistics That Were Not Ordered)," Belorusskaya Delovaya Gazeta, No. 1483, November 26, 2004.

Bulgakau, Valer, "Forum," on-line conference of the Belarusian Service of Radio Liberty, May 31, 2006 [www.svaboda.org].

Bulgakau, Valerka, "Vybary Prezydenta Kreolau (Elections of the President of the Creoles)," Arche, 4, 2001 [www.arche.home.by/2001-4/bulha401.htm.001].

Bykovskiy, Pavlyuk, "Reiting Lukashenko i yego konkurentov" (Rating of Lukashenka and his Competitors), 2006 [http://ru.belaruselections.info/current/2006/sociology/0022756].

Center for Political Studies and Public Opinion Research, Institute of Social Sciences, Belgrade, Serbia [www.cpijm.org.yu].

"Chamu Alyaxandar Milinkevich vystupau na telebachani pa-raseisku? (Why Did Alexander Milinkevich Speak Russian on Belarusian TV?)," Belarusian Service Radio Liberty, February 24, 2006 [www.svaboda.org].

Chivers, C. J., "In 50-Yard Square in Belarus, a Country Within," The New York Times, March 23, 2006, A1, A6.

Drakokhrust, Yuriy, “Gde konchayetsya Belorussiya? (Where Does Belarus End?),” Neprikosnovennyy Zapas, 47:108-119, 2006.

Dynko, Andrei, "Patrabuyu nemagchymaga—budzte realistami (Demanding the Impossible: Being Realists)," Nashe Mneniye, September 4, 2006 [www.nmnby.org]

Feakins, Melanie and Luiza Bialasiewicz, "Trouble in the East': The New Entrants and Challenges to the European Ideal," Eurasian Geography and Economics, 47, 6:647-661, 2006.

Feduta, Alyaksandr, "Kollektivnyy politinformator i agitator. Izbrannyye mesta iz uchebnikov po gosudarstvennoy ideologii Respubliki Belarus (A Collective Political Informer and Agitator. Excerpts from the Textbooks on the National Ideology of the Republic of Belarus)," Neprikosnovennyy Zapas, 47:120-144, 2006a.

Feduta, Alyaksandr, "Krayna glukhikh: Otechestvo v opasnosti (The Country of the Deaf: The Fatherland Is in Peril)," Nashe Mneniye, June 17, 2006 [www.nmnby.org].

"52 percent Belorusov schitayut sebya sovetskimi lyudmi (52 Percent of Belarusians Identify Themselves as Soviet People), Belorusskiye novosti," April 23, 2006; [www.naviny.by].

IISEPS, November 2003 National Survey, 2003 [http://www.iiseps.org/].

IISEPS, December 2005 National Survey, 2005 [http://www.iiseps.org/12-05-06.html].

IISEPS, National surveys [http://www. Iiseps.org/4-06-7.html;], last accessed November 2006.

IMF, Republic of Belarus: Selected Issues. Washington, DC: International Monetary Fund, IMF Country Report No. 05/217, June 2005.

Ioffe, Grigory, "Understanding Belarus: Belarusian Identity," Europe-Asia Studies, 4:1241-1272, 2003.

Ioffe, Grigory, "Culture Wars, Soul-Searching, and Belarusian Identity," East European Politics and Societies, May 2007 (forthcoming).

Kirillov, Pavel, "23 percent Belorusov boyatsya diktatury i repressii” (23\% of Belarusians Fear Dictatorship and Repressions), Belorusskiye novosti, May 31, 2005 [www.naviny.by].

Kirillov, Pavel, "I vlasti i oppositsiya — chrezmernyye optimisty (Both the Government and Opposition Are Excessive Optimists), Belorusskiye novosti, April 21, 2006b [www.naviny.by].

Kirillov, Pavel, "Oppozitsia mozhet poluchit vtoroy tur s pomoshchyu storonnikov Lukashenko (The Opposition May Get the Second Round Owing to Lukashenka Supporters)," Belorusskiye Novosti, March 7, 2006a [www.naviny.by].

Korosteleva, Elena, Colin W. Lawson, and Rosalind Marsh, eds., Contemporary Belarus: Between Democracy and Dictatorship. London, UK: RouteledgeCurzon, 2003. 
Lepeshko, Boris, "Traditsiya i avtoritet" (Tradition or Authority)," Belarus Segodnya, August 9, 2006.

Lukashenka, Alyaksandr, Press Conference for Russia's Provincial Media, September 29, 2006 [http://www.president.gov.by/press31104.html].

"Lukashenko: V zemlyanki poidiom no na shantazh ne poddadimsya (Lukashenka: We Will Live in Dugouts but Not Succumb to Blackmail)," Belorusskiye Novosti, December 29, 2006 [http://www .naviny.by/rubrics/economic/2006/12/29/ic_news_113_264742/].

Martovskaya, Svetlana, “Pochemu Belarus' golosuyet za Lukashenko (Why Belarus Voted for Lukashenko)," Telegraf, September 14, 2005 [http://www.inosmi.ru/translation/222228.html].

Matskevich, Vladimir, "Zhdat seryoznykh postupkov ot takoy oppozitsii ne prikhoditsya (There Is No Chance this Opposition is Up to Something Serious)," Belorusskiye Novosti, September 21, 2006 [www.naviny.by].

Medvetsky, Aleksei, "Chuzhoy president—svoy president (Someone Else's President—One's Own President)," Nashe Mneniye, June 28, 2006 [www.nmnby.org]

Meckovskaya, Nina B., Belorusskiy yazyk: Sotsiolingvisticheskiye ocherki (Belarusian Language: Sociolinguistic Essays). Munich, Germany: Verlag Otto Sagner, 2003.

Ministerstvo Statistiki i Analiza (Ministry of Statistics and Analysis), 2005 [http://belstat.gov.by/ homep/ru/indicators/labor.php.]

Myers, Steven Lee, "Russia-Belarus Gas Deal Averts Feared Disruptions in Europe," The New York Times, January 1, 2007a, A3.

Myers, Steven Lee, "Belarus and Russia Trade Accusations Over Crude Oil Cutoff," The New York Times, January 9, 2007b, A10.

"New Pipeline to Bypass Belarus," The New York Times, February 6, 2007, C6.

Nikolyuk, Sergey, "Dogovor 2006 (Agreement 2006)," Nashe Mneniye, April 18, 2006a [www.nmnby.org].

Nikolyuk, Sergey, "Obshestvennoye mneniye kak sub”yekt belorusskoy politiki (Public Opinion as a Belarusian Political Actor)," Nashe Mneniye, August 2, 2006b [www.nmnby.org].

Nikolyuk, Sergey, "Navedeniye poradka (Putting in Order)," Nashe Mneniye, August 18, 2006c [www.nmnby.org].

"Okonchatel'nyye itogi prezidentskikh vyborov (Final Results of the Presidential Elections)," Belorusskiye Novosti, March 23, 2006 [www.naviny.by].

Panyushkin, Valeriy, "Belorusskoy oppozitsii ne khvatayet narodnogo gneva (Belarusian Opposition Is in Need of Public Indignation)," Kommersant, March 18, 2006 [http://www.kommersant.ru/doc .html?DocID=658651\&IssueID=30045].

Pazniak, Zianon, "Ya budu uzdelnichat u prezidentskikh vybarakh 2006 godu (I Will Be Taking Part in the 2006 Presidental Elections)," Belarusian Service, Radio Liberty, October 5, 2005 [www .svaboda.org]

Piontkovskiy, Andrey, "Lukashenko stal istinnym otsom Belorusskoy nezavisimosti (Lukashenka Has Become the True Father of Belarusian Independence)," AFN, July 6, 2006 [www.afn.by].

"Po dannym sotsiologov laboratorii Novak, negativnyy reiting Lukashenko rastyot (According to the Sociological Data of the Novak Lab, the Negative Rating of Lukashenka Is on the Rise)," interview with Andrey Vardomatskiy, Russia online, May 8, 2001 [http://www.rol.ru/news/misc/ newssng/01/05/08_026.htm], accessed in May 2001.

Polesskiy, Yanov, "Razocharovat'sya v bolshinstve (To Get Disappointed in the Majority)," Nashe Mneniye, April 27, 2006 [www.nmnby.org/print/0604/27-d_prn.html].

Pozniak, Kirill, "Belorusy schitayut, chto stali zhit luchshe (Belarusians Believe That Their Life Has Improved), Belorusskiye Novosti, August 6, 2006 [www.naviny.by].

Rabchuk, Mykola, Vid Malorossii do Ukraini (From Little Russia to Ukraine). Kyiv, Ukraine: Kritika, 2000.

Rubinov, Anatoliy, "Yescho raz ob ideologii" (Once Again about Ideology)," Belarus Segodnya, July 28, 2006.

Rykiel, Zbigniew, Podstawy Geografii Politycznej (Foundations of Political Geography). Warsaw, Poland: Polskie Wydawnictwo Economiczne, 2006. 
Shevtsov, Yuriy, Obyedinyonnaya Natsiya: Fenomen Belarusi (United Nation: The Phenomenon of Belarus). Moscow, Russia: Yevropa, 2005.

Shybeka, Zakhar, "Forum: Online Conference," July 5, 2006, Belarusian Service, Radio Liberty [www.svaboda.org].

Silitski, Vitaly, "Pamiatats, shto dyktatyry ruinuyutsa (To Remember That Dictatorships Fail)," Arche, 7, 2006 [http://arche.bymedia.net/2006-7/silicki706.htm].

Struve, Alena, "Yakiye paraleli pamizh belaruskai i ukrainskai situatsiyai? (What are the Parallels between the Belarusian and Ukrainian Situations?)," Belarusian Service, Radio Liberty, March 21, 2006 [www.svaboda.org].

"Tsi magli padzei 19-25 sakavika skonchitsa inaksh? (Could the Events of 19-25 March End Up Differently?)," Prazhsky Accent, talk show of Belarusian Service, Radio Liberty, April 2, 2006 [www .skaboda.org].

“Tsi zyavilas' u Belarusi alternatyva Alyaksandru Lukashenku? (Does an Alternative to Lukashenka Appear in Belarus?)," Prazhsky Accent, talk show of Belarusian Service, Radio Liberty, January 29, 2006 [www.svaboda.org].

Vardomatskiy, Andrey, "Belarus i mir: Sotsiologicheskoye issledovaniye (Belarus and the World: A Sociological Study)," Analiticheskiy Byulleten’ Belorusskikh Fabrik Myusli, 2:20-23.

"Voprosy prezidentu. 1207 voprosov po teme 'Rossiya i Belarus' (Questions to the President. 1207 Questions on the topic of 'Russia and Belarus')" [http://president.yandex.ru/theme.xml?id=159], accessed October 5, 2006.

"Vybory prezidenta Belorussii (Presidential Election in Belarus)," Gosti (talk show), Ekho Moskvy, (Moscow-based radio channel), March 20, 2006 [www.echo.msk.ru/guests/9807].

Weeks, Theodore, “'Us' or 'Them'? Belarusians and Official Russia, 1863-1914," Nationalities Papers, 31, 2, June 2003.

World Bank, Belarus: Window of Opportunity to Enhance Competitiveness and Sustain Economic Growth. Washington, DC: The World Bank, 2005 [http://web.worldbank.org/WBSITE/ EXTERNAL/COUNTRIES/ECAEXT/BELARUSEXTN/0,,contentMDK:20726033].

"Yakoye palitychnaye znacheniye meli tydniovyya pratesty apazytsii? (What Was the Political Significance of the Week-Long Protest of the Opposition?)," Prazhsky Accent (talk show of the Belarusian Service of Radio Liberty), April 26, 2006 [www.svaboda.org].

Yakubovich, Pavel, "Rozhdionnyy padat' letat ne mozhet (He Who's Cut Out to Fall Cannot Fly)," Belarus Segodnya, February 23, 2006 [www.sb.by].

Yakubovich, Pavel, "Politkhirurgiya (Political Surgery)," Belarus Segodnya, January 13, 2007 [http:// www.sb.by/article.php?articleID=56194].

Zayiko, Leonid, "Na Porsche mezhdu Brusselem i Moskvoy (Driving a Porsche between Brussels and Moscow)," Nashe Mneniye, September 11, 2006 [www.nmnby.org]. 